\title{
MACRADENIA (ORCHIDACEAE): A CONFIRMED GENUS FOR COSTA RICAN FLORA
}

\author{
Franco Pupulin ${ }^{1}$ and Carlos Ossenbach $\mathrm{S}^{2}$ \\ ' Jardín Botánico Lankester, Universidad de Costa Rica \\ Research Associate, Marie Selby Botanical Gardens \\ P.O. Box 1031-7050 Cartago, Costa Rica, A.C. - fpupulin@cariari.ucr.ac.cr \\ ${ }^{2}$ Orquideario 25 de mayo, Sabanilla de Montes de Oca \\ P.O.Box 136-1150 La Uruca, Costa Rica, A.C. - caossenb@racsa.co.cr
}

\begin{abstract}
The presence of the orchid Macradenia brassavolae Rchb.f. is confirmed in Costa Rica on the basis of two collections from the Caribbean drainage. The species is described and illustrated.

RESUMEN. Se confirma la presencia en Costa Rica de la orquídea Macradenia brassavolae Rchb.f. con base en dos recolectas de la vertiente Caribe del país. Se presenta una descripción y una ilustracón de la especie.
\end{abstract}

KeY WoRDS: Orchidaceae, Macradenia brassavolae, Costa Rica

The genus Macradenia R. Br. includes some twelve species widely distributed in the Neotropics, from southern Florida to Brazil and Bolivia. Species in the genus present a well developed clinandrium and prominent rostellum, with a elongate anther which lies dorsally on the column. Traditional systematics place Macradenia in a broad subtribe Oncidiinae s.1. (Dressler 1981, 1993a) or in more narrowly defined subtribes Notyliinae (Bentham 1881, Senghas 1995) and Macradeniinae (Schlechter 1926, Szlachetko 1995), mainly defined by the position of the anther and the shape of rostellum remnant. Recent molecular analysis of the Oncidiinae (M. Whitten, pers. comm.) show the position of Macradenia into a well defined clade including several orchid genera with "spiranthoid" column (i.e. dorsal anther and terminal rostellum), largely corresponding to subtribe Notyliinae sensu Bentham (1881). Due to gross affinities in column structure, Schlechter (1915) reduced Warmingia Rchb.f. into synonymy under Macradenia, but molecular data (M. Whitten, pers. comm.) do not support this interpretation.

Macradenia brassavolae was originally described by Reichenbach $f$. from Guatemala
(Warszewicz s.n., W-R 37663!, the type), and it was successively reported in Mesoamerica from México (Soto Arenas 1988), Belize (Halcrow \& Halcrow 1967), Honduras (Hamer 1984, distribution map), Nicaragua (Hamer 1984), and Panama (Allen 1949). In Costa Rica it was first recorded by Mora-Retana and García (1992). Because no specimens of M. brassavolae are kept in the national herbaria studied by the authors, it is likely they had no opportunity to examinate any actual specimens collected in the country. Dressler (1993b) included Costa Rica in the distribution range of M. brassavolae, but Atwood and Mora-Retana (1999: 88) only indicated that the species should be expected in Costa Rica, and formally excluded it from the treatment of Subtribe Oncidiinae for the Flora Costaricensis. However, we can substantiate here the presence of $M$. brassavolae in Costa Rica on the basis of two collections from Caribbean drainage lowlands:

Costa RicA. Limón: abandonos enguamillados, húmedos, pantanos, yolillosos de Goldengrove, drenaje del Río Reventazón, 15 m, octubre 23, 1951, Antonio Molina y Paul J. Shank s.n. (epífita, flor color carne) (EAP, photo!).

Costa Rica. Heredia: Sarapiquí, La Rambla, 

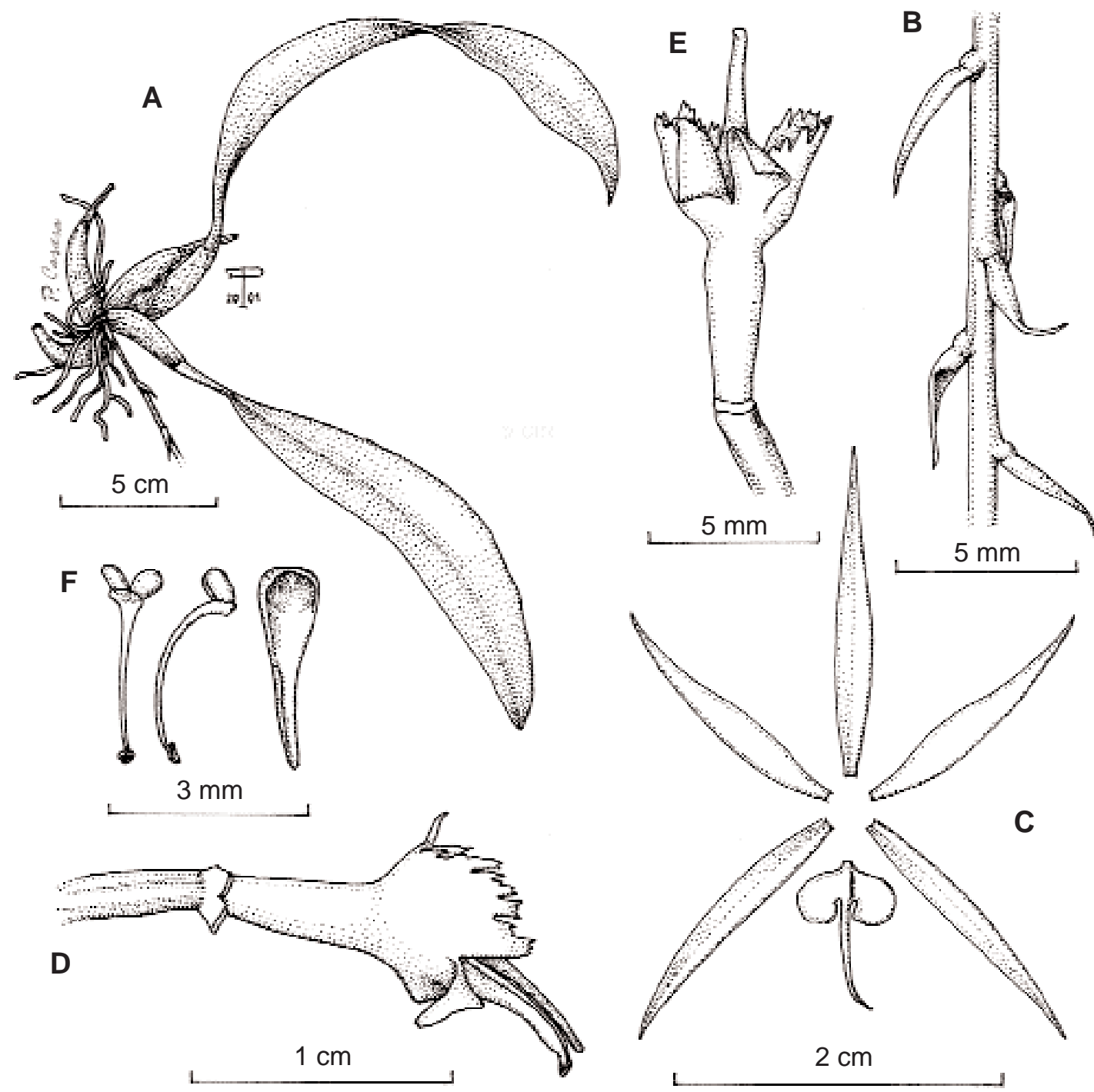

Figure 1. Macradenia brassavolae Rchb.f. A - Habit. B - Rhachis. C - Dissected perianth. D - Column, lateral view. E - Column, ventral view. F - Pollinarium and anther cap. A, from the living specimen; B-F, from rehydrated material. ILlustration VOUCHER: C. Ossenbach 122 (USJ).

$83^{\circ} 54^{\prime}$ W, $10^{\circ} 24^{\prime}$ N, ca. 60 m, collected by Santos Muñoz Vega, 1999, flowered in cultivation at Horquetas de Sarapiquí, 20 Oct. 2001, C. Ossenbach 122 (USJ!).

The following description is provided, based on Costa Rican material:

Macradenia brassavolae Rchb.f., Bot. Zeit. (Berlin) 10: 734. 1852.

FIG. 1.

Serrastylis modesta Rolfe, Bull. Misc. Inform.

1894: 158. 1894. Macradenia modesta (Rolfe)
Rolfe, Orch. Rev. 4: 357. 1896. TYPE: Colombia. Hab. Andes of New Grenada, Cauca, F.C. Lehmann s.n. (K).

Plant epiphytic, cespitose, to about $20 \mathrm{~cm}$ tall. Roots slender, flexuous, glabre. Pseudobulbs conicpyriform to subcylindric, rounded in section, 3.2 $\mathrm{cm}$ long, $0.8 \mathrm{~cm}$ wide, monophyllous, subtended at the base by $2-3$ lanceolate-triangular, acute, scarious bracts to $2.4 \mathrm{~cm}$ long. Leaf narrowly elliptic to linear-elliptic, subcoriaceous, obtuse to acute, 17- 
$20 \mathrm{~cm}$ long, 2.8-3.1 cm wide, narrowing at the base into a conduplicate petiole about $1.3 \mathrm{~cm}$ long. Inflorescence lateral, from the base of pseudobulb, a slender, pendulous, many-flowered raceme to 17 $\mathrm{cm}$ long; peduncle terete, to $6 \mathrm{~cm}$ long, with several narrowly triangular, acuminate, scarious bracts. Floral bracts narrowly triangular, provided at the base with a subglobose thickening, to $8 \mathrm{~mm}$ long. Flower with pale brown to rose-brown sepals and petals, the margins yellowish green, the lip white with purple-brown blotches. Sepals subsimilar, narrowly lanceolate, acuminate, $20 \mathrm{~mm}$ long, $2.3 \mathrm{~mm}$ wide. Petals simillar to the sepals, widest at the base, $16 \mathrm{~mm}$ long, $2.5 \mathrm{~mm}$ wide. Lip sessile, 3lobed, obcordiform, $9 \mathrm{~mm}$ long; $6 \mathrm{~mm}$ wide, the lateral lobes suborbicular, rounded, the median lobe linear-filiform, the disc with a low longitudinal keel from the base to the insertion point of midlobe. Column fleshy, subterete from a narrow base, $7 \mathrm{~mm}$ long, abruptly dilated above into a deeply cucullate clinandrium, the margins conspicuously lacerate, provided ventrally with two subquadrate flaps surrounding the stigma, the rostellum long, narrowly linear. Anther cap narrowly triangular, cucullate at the base, 2-celled. Pollinia 2, obovate, slightly complanate, on a long, linear, apically dilated stipe; viscidium elliptic.

Ecology and Phenology: Epiphytic in tropical rain forest, basal belt, 15-100 m, usually in very wet sites, restricted to the Caribbean drainage. Flowering occurs at least from October to December.

Conservation STAtus: It is rather surprising that such an attractive species, with its long inflorescences and pretty flowers, remained so far unknown to the many orchid growers living in the country, but the scattered available data suggest it should be considered a rare species in northern Mesoamerica. In Costa Rica M. brassavolae is known only from two collections, and a single specimen collected in 1928 (Englesing 275, AMES, photo!) is so far the only record of this species from Nicaragua (Hamer 1984, 2000).

Acknowledgements. We would thank Pilar Casasa for sketching the plant habit in situ. Acknowledgements are extended to Santos Muñoz
Vega for loaning us plants of his personal collection, to Robert L. Dressler for sharing information about herbarium records, to Gustavo Romero (AMES), Dinie Espinal-Rueda and José Linares from the Escuela Agrícola Panamericana (E1 Zamorano), Honduras, for sending copies of critical material kept in their herbaria.

\section{Literature Cited}

Allen, P.H. 1949. Orchidaceae. In R.E. Woodson and R.W. Schery (ed.), Flora of Panama, Part. 3, Fasc. 4. Ann. Missouri Bot. Gard. 36: 1-132.

Atwood, J.T. \& D.E. Mora-Retana. 1999. Family \#39 Orchidaceae: Tribu Maxillarieae: Subtribes Maxillariinae and Oncidiinae. In W. Burger (ed.), Flora Costaricensis. Fieldiana, Bot. n.s. 40: 1-182.

Bentham, G. 1881. Ordo CLXIX. Orchideae. In G. Bentham \& J.D. Hooker, Genera Plantarum, pp. 460636. Kew Herbarium, London.

Dressler, R.L. 1981. The orchids, natural history and classification. Harvard University Press, Cambridge. 1993a. Phylogeny and classification of the orchid family. Dioscorides Press, Portland. 1993b. Field guide to the orchids of Costa Rica and Panama. Cornell University Press, Ithaca and London.

Halcrow, M. \& M.L. Halcrow. Orchids of Belize. Government of Belize: pp. 90-91.

Hamer, F. 1984. Orchids of Nicaragua, Part 4. Icon. Pl. Trop. 11: sub pl. 1032. 2000. Orchidaceae. In W.D. Stevens, C. Ulloa, A. Pool \& O.M. Montiel (eds.), Flora de Nicaragua. Monogr. Syst. Bot. Missouri Bot. Gard. 85.

Mora-Retana, D.E. \& J.B. García. 1992. Lista actualizada de la orquídeas de Costa Rica (Orchidaceae). Brenesia 37: 79-124.

Schlechter, R. 1915. Macradenia. Die Orchidee: 461-462. 1926. Das System der Orchidaceen. Notizbl. Bot. Gart. Mus. Berlin-Dahlem 9(88): 563-591.

Senghas, K. 1995. Subtribus Notyliinae. In R. Schlechter, Die Orchideen, 3. Aufl., Bd. I: 1977-1994.

Soto Arenas, M.A. 1988. Listado actualizado de las orquídeas de México. Orquídea (Méx.) 11: 233-277.

Szlachetko, D.L. 1995. Systema Orchidalium. Fragm. Flor. Geobot. Suppl. 3: 1-152. 